\title{
ANALISIS KESALAHAN BERBAHASA PADA SOAL UJIAN PELAJARAN BAHASA INDONESIA DI SMA
}

\author{
Shinta Wardani, Budhi Setiawan, Sri Hastuti \\ Universitas Sebelas Maret \\ Email: sintawardani.97@gmail.com
}

\begin{abstract}
Abstrak: Penelitian ini bertujuan untuk mendeskripsikan dan menjelaskan: (1) jenis-jenis kesalahan berbahasa pada soa; (2) penyebab kesalahan berbahasa pada soal; (3) efek komunikasi yang ditimbulkan akibat kesalahan berbahasa pada soal Penilaian Akhir Semester mata pelajaran Bahasa Indonesia kelas XI SMA Negeri Di Wilayah Sukoharjo; (4) pemahaman guru terhadap kaidah penyusunan soal; dan (5) ketepatan penyusunan soal Penilaian Akhir Semester mata pelajaran Bahasa Indonesia kelas XI SMA Negeri di wilayah Sukoharjo berdasarkan kaidah penyusunan soal. Jenis penelitian ini adalah penelitian kualitatif. Penelitian kualitatif kali ini bersifat content analysis (analisis isi) dengan sumber data utama soal Penilaian Akhir Semester mata pelajaran Bahasa Indonesia kelas XI SMA Negeri di wilayah Sukoharjo . Teknik pengambilan sampel dengan purposive sampling dan snowball sampling. Penelitian ini menggunakan triangulasi sumber data dan triangulasi metode sebagai uji validitas data. Hasil analisis temuan dapat dijelaskan sebagai berikut. (1) kesalahan berbahasa dalam soal Penilaian Akhir Semester berupa kesalahan ejaan, kata, dan kalimat; (2) kesalahan berbahasa disebabkan oleh faktor internal dan faktor eksternal; (3) kesalahan berbahasa menimbulkan efek komunikasi yang signifikan karena peserta didik merasa kesulitan dalam memahami maksud soal; (4) guru kurang memahami kaidah penyusunan soal baik secara teori maupun praktik; (5) Kaidah penyusunan soal yang terdapat dalam soal Penilaian Akhir Semester mata pelajaran Bahasa Indonesia kelas XI SMA Negeri di wilayah Sukoharjo belum sepenuhnya menggunakan kaidah penyusunan soal yang sedang berlaku baik dari aspek materi dan aspek konstruksi.
\end{abstract}

Kata kunci: kesalahan berbahasa Indonesia, soal penilaian semester, kaidah penyusunan soal.

\section{LANGUAGE ERROR ANALYSIS OF INDONESIAN LANGUAGE FINAL TEST IN SENIOR HIGH SCHOOL}

\begin{abstract}
This research aims to describe and explain: (1) the kinds of mistakes-speaking on the matter, (2) the cause of the error on the question of language, (3) communication effects caused due to an error on a question of language Final Assessment subjects Indonesian Language grade XI public senior high school in Sukoharjo Area school, (4) understanding teacher against the rule drafting problem, and (5) precision drafting problem Final Assessment subjects Indonesian Language grade XI public senior high school in Sukoharjo based on rules of preparation of a matter. This type of research is qualitative research. Qualitative research this time is both a content analysis (content analysis) with the main data source about the Final Assessment of the Odd Semester subjects Indonesian Language grade XI public senior high school in Sukoharjo . The technique of sampling with purposive sampling and snowball sampling. This research uses data sources triangulation and triangulation method as a test of the validity of the data. The results of the analysis of the findings can be explained as follows; (1) errors in language reserved assessment of the end of the Semester in the form of spelling errors, Word, and sentence; (2) language mistakes caused by internal factors and external factors; (3)the effect of communication language errors are significant because the learners feel difficulty in understanding the intent of the question; (4) teachers less understand rule drafting reserved either in theory or practice; (5) the question of the drafting of the Rules contained in the matter of the assessment of the finalsemester subjects Indonesian Language grade XI public senior high school in Sukoharjo is not fully using the rules of preparation of the matter that is being applies both from the aspect of material and construction aspects.
\end{abstract}

BASASTRA Jurnal Bahasa, Sastra, dan Pengajarannya

Volume 8 Nomor 1, April 2020, P-ISSN 2302-6405, E-ISSN 2714-9765 
Keywords: Indonesian language errors, semester assessment, questions drafting rule.

\section{PENDAHULUAN}

Kegiatan pembelajaran merupakan suatu proses interaksi antarpeserta didik, antara peserta didik dengan guru, dan sumber belajar pada suatu lingkungan belajar. Hal tersebut tercantum dalam Permendikbud No. 104 tahun 2014 tentang pembelajaran. Hasil dari kegiatan pembelajaran tersebut adalah bertambahnya keterampiln dan pengetahuan peserta didik yang dapat diukur dengan instrumen evaluasi atau alat penilaian yang sesuai.

Alat penilaian yang digunakan sebagai tolok ukur keberhasilan dalam kegiatan pembelajaran salah satunya, yaitu soal. Soal merupakan bagian dari tes yang di dalamnya berisikan pertanyaanpertanyaan berkaitan dengan keberhasilan yang akan dinilai. Melalui tes, maka guru mendapatkan informasi mengenai keberhasilan peserta didik dalam hal mengasai tujuan yang sebelumnya sudah ditetapkan dalam kurikulum yang sedang berlaku. Selain itu, soal juga merupakan salah satu bentuk tes sumatif yang dilaksanakan di setiap jenjang pendidikan (Tritantining, 2013:2). Tes sumantif merupakan tes yang diberikan dengan tujuan mengetahui pencapaian atau penguasaan peserta didik pada bidang tertentu yang dilakukan dikhir unit program, seperti caturwulan, akhir semester, dan akhir tahun.

Penyusunan sebuah soal, khususnya soal PAS sangat berkaitan erat dengan dua hal agar soal yang disusun berupa soal yang baik. Dua hal tersebut yang pertama, yaitu memperhatikan langkah-langkah untuk menentukan suatu objek yang ditanyakan seperti: analisis kurikulum, analisis sumber materi pelajaran, menetapkan tujuan tes, menentukan kisikisi. Kedua, pikiran, gagasan, dan maksud bentuk-bentuk pertanyaan soal harus dipikirkan dan direnungkan dengan baik dan benar. Hal tersebut ada kaitannya dengan kaidah kebahasaan. Pada saat menyusun sebuah soal, seorang penyusun soal harus memiliki kemampuan berbahasa yang baik. Karena hal tersebut sangat berpengaruh pada kualitas soal yang dibuat. Soal yang berperan sebagai instrumen pengukur kemampuan hasil pembelajaran yang telah dilakukan oleh peserta didik harus terbebas dari kesalahan berbahasa. Apabila seorang penyusun soal tidak jeli dalam menggunakan bahasa maka bahasa tersebut tidak dapat digunakan secara baik pula. Hal ini akan berdampak negatif pada peserta didik, mereka akan mengalami kesulitan untuk memahami soal sehingga tidak mampu menjawab soal tersebut dengan benar. Akibatnya juga akan berdampak dalam proses penilaian.

Saat ini banyak sekali ditemukan kesalahan dalam penggunaan kata maupun kalimat efektif dalam pembelajaran ataupun dalam pembuatan soal sebagai penilaian hasil pembelajaran khususnya di wilayah kabupaten Sukoharjo. Terdapat beberapa kemungkinan mengapa hal tersebut terjadi diantaranya, yaitu kurangnya ketelitian dalam penggunaan kata atau kalimat, kurangnya kepedulian dengan kaidah-kaidah kebahasaan yang sedang berlaku, kebiasaan yang salah, kurang memahami dan menguasai penggunaan kata dan kalimat efekif, tidak ada evaluasi, serta rentan waktu yang sangat singkat dalam pembuatan soal sehingga guru kurang memperhatikan penggunaan kaidah secara benar asalkan soal yang dibuat selesai tepat waktu.

Berdasarkan dari latar belakang yang telah dijabarkan tersebut, peneliti tertarik untuk menganalisis kesalahan yang terdapat dalam soal Penilaian Akhir Semester (PAS) agar dapat diketahui sampai mana tingkat pemahaman dan ketelitian seorang guru dalam 
menggunakan kaidah kebahasaan yang benar sesuai dengan kaidah yang sedang berlaku. Peneliti mengambil data berupa naskah soal di wilayah Kabupaten Sukoharjo karena belum pernah dijadikan tempat penelitian untuk penelitian serupa sebelumnya. Oleh sebab itu, penelitian dengan judul "Analisis Kesalahan Berbahasa pada Soal Penilaian Akhir Semester Mata Pelajaran Bahasa Indonesia Kelas XI SMA Negeri di Wilayah Sukoharjo " perlu dilakukan.

Rumusan masalah pada penelitian ini adalah (1) Bagaimanakah jenis kesalahan berbahasa pada soal Penilaian Akhir Semester mata pelajaran Bahasa Indonesia kelas XI SMA Negeri di wilayah Sukoharjo? (2) Bagaimanakah faktor yang menyebabkan kesalahan berbahasa pada soal Penilaian Akhir Semester mata pelajaran Bahasa Indonesia kelas XI SMA Negeri di wilayah Sukoharjo? (3) Bagaimanakah dampak yang ditimbulkan dari kesalahan berbahasa pada soal Penilaian Akhir Semester mata pelajaran Bahasa Indonesia kelas XI SMA Negeri di wilayah Sukoharjo? (4) Bagaimanakah pemahaman guru terhadap kaidah penyusunan soal Penilaian Akhir Semester mata pelajaran Bahasa Indonesia kelas XI SMA Negeri di wilayah Sukoharjo? (5) Bagaimanakah ketepatan soal Penilaian Akhir Semester mata pelajaran Bahasa Indonesia kelas XI SMA Negeri di wilayah Sukoharjo yang disusun guru dengan kaidah penyusunan soal.

\section{METODE PENELITIAN}

Jenis penelitian ini adalah penelitian kualitatif. Penelitian kualitatif kali ini bersifat content analysis (analisis isi) dengan sumber data utama soal mata pelajaran Bahasa Indonesia kelas XI SMA Negeri di wilayah Sukoharjo tahun ajaran 2018/2019. Teknik pengambilan sampel dengan purposive sampling yaitu memilih soal-soal yang berupa soal objektif dengan pilihan ganda. Soal tahun ajaran 2018/2019 dipilih karena data yang tersedia masih lengkap dan mudah didapatkan.

Untuk menguji validitas data dilakukan dengan triangulasi teori, yaitu untuk mengidentifikasi bentuk dan jenis kesalahan bahasa digunakan beberapa perspektif teori yang berbeda, misalnya kesalahan pilihan kata menggunakan teori Gorys Keraf dan Abdul Chaer, sedangkan kesalahan kalimat menggunakan teori kalimat Samsuri dan Verhaar. Selain itu, uji validitas juga digunakan triangulasi metode yaitu menguji valid tidaknya data dari guru dicek melalui wawancara dengan siswa. Untuk analisis data dilakukan secara kuantitatif dan kualitatif. Analisis kuantitatif dilakukan terhadap data yang berupa frekuensi dan persentase kesalahan untuk menentukan jenis kesalahan yang dominan dan yang paling sedikit. Analisis kualitatif dilakukan untuk mengolah data penyebab dan dampak adanya kesalahan bahasa melalui wawancara. Model analisis yang diterapkan adalah analisis mengalir atau flow model of analysis (Miles dan Huberman, 2004).

\section{HASIL DAN PEMBAHASAN}

Dalam hasil penelitian ini akan mendeskripsikan mengenai pemerolehan hasil dari penelitian yang telah dilakukan. Hasil penelitian tersebut meliputi jenis kesalahan berbahasa, faktor penyebab kesalahan berbahasa, dampak yang ditimbulkan, pemahaman guru terhadap kaidah penyusunan soal, dan kaidah penyusunan soal dalam Penilaian Akhir Semester Gasal mata pelajaran Bahasa Indonesia kelas IX SMA Negeri di wilayah Sukoharjo.

\begin{tabular}{|c|c|c|}
\hline \multicolumn{3}{|c|}{ Jenis Kesalahan Berbahasa } \\
\hline Kegiatan & menganalisis & dalam \\
\hline penalitian ini & berupa & kegiatan \\
\hline mengidentifikasi & jenis & kesalahan \\
\hline penggunaan bahasa & a Indonesia & als \\
\hline Kesalahan-kesalaha & & terseb \\
\hline dang eja & & \\
\hline
\end{tabular}


Tabel 1. Kesalahan Berbahasa pada Soal

\begin{tabular}{|c|c|c|c|c|}
\hline No & $\begin{array}{c}\text { Katego } \\
\text { ri } \\
\text { Kesala } \\
\text { han }\end{array}$ & $\begin{array}{c}\text { Jenis } \\
\text { Kesalaha } \\
\text { n }\end{array}$ & $\begin{array}{c}\text { Jumlah } \\
\text { Kesalaha } \\
\text { n }\end{array}$ & $\begin{array}{l}\mathrm{Ju} \\
\mathrm{ml} \\
\mathrm{ah}\end{array}$ \\
\hline \multirow[t]{3}{*}{1.} & \multirow[t]{3}{*}{ Ejaan } & $\begin{array}{l}\text { Pemakaia } \\
\mathrm{n} \text { tanda } \\
\text { baca }\end{array}$ & 81 & \multirow[t]{3}{*}{9} \\
\hline & & $\begin{array}{l}\text { Pemakaia } \\
\text { n huruf }\end{array}$ & 26 & \\
\hline & & $\begin{array}{l}\text { Penulisan } \\
\text { kata }\end{array}$ & 12 & \\
\hline \multirow[t]{2}{*}{2.} & \multirow[t]{2}{*}{ Kata } & $\begin{array}{l}\text { Pilihan } \\
\text { ketepatan } \\
\text { kata }\end{array}$ & 27 & \multirow[t]{2}{*}{46} \\
\hline & & $\begin{array}{l}\text { Pengguna } \\
\text { an kata } \\
\text { baku }\end{array}$ & 19 & \\
\hline \multirow[t]{2}{*}{3.} & \multirow[t]{2}{*}{$\begin{array}{l}\text { Kalima } \\
\mathrm{t}\end{array}$} & $\begin{array}{l}\text { Kesatuan } \\
\text { gagasan }\end{array}$ & 31 & \multirow[t]{2}{*}{37} \\
\hline & & $\begin{array}{l}\text { Kehemat } \\
\text { an } \\
\text { kalimat }\end{array}$ & 6 & \\
\hline & \multicolumn{3}{|c|}{ Jumlah Keseluruhan } & $\begin{array}{l}20 \\
2\end{array}$ \\
\hline
\end{tabular}

Tabel 1 di atas merupakan pemaparan jumlah total hasil penelitian kesalahan berbahasa pada soal Penilaian Akhir Semester gasal mata pelajaran Bahasa Indonesia kelas XI SMA Negeri di wilayah Sukoharjo. Selanjutnya, peneliti akan menghitung persentase dari setiap jenis kesalahan berbahasa. Penghitungan presentase kesalahan berbahasa pada soal dapat dihitung dengan rumus berikut.

Presentase Kata $=\frac{46}{202} \times 100 \% \quad=$ $22,77 \%$

Presentase Kalimat $=\frac{37}{202} \times 100 \%=18$, $31 \%$

Kesalahan penggunaan bahasa Indonesia pada soal Penilaian Akhir Semester gasal mata pelajaran Bahasa Indonesia kelas XI SMA Negeri di wilayah Sukoharjo ditemukan cukup banyak. Oleh sebab itu, tidak semua kesalahan yang ditemukan tersebut dapat dijelaskan secara terperinci di sini. Peneliti hanya menjelaskan beberapa jenis kesalahan sebagai contoh. Pendeskripsian contoh kesalahan akan peneliti urutkan sesuai dengan kategori. Supaya memberikan kejelasan dalam penyajian jenis kesalahan tersebut perlu dijelaskan hal-hal sebagai berikut: (1) di depan bentuk penyusunan soal yang salah di beri tanda asterisk (*); (2) untuk menunjukkan letak kesalahan diberi garis bawah pada bentuk-bentuk yang salah, baik bentuk kesalahan ejaan, kata, maupun kalimat; (3) di bagian akhir atau belakang setiap bentuk penyusunan soal yang salah disertakan nama mata pelajaran, bentuk soal, dan nomor soal. Hasil penelitian terkait dengan permasalahan tersebut dapat dijabaran seperti berikut ini.

Pemakaian huruf dalam soal harus sesuai dengan Pedoman Umum Ejaan Bahasa Indonesia (PUEBI) yang sedang berlaku. Di bawah ini merupakan bentukbentuk kesalahan pemakaian huruf yang

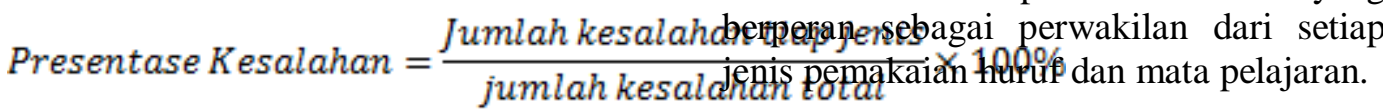

Dengan demikian, dapat dihitung presentase kesalahan berbahasa Indonesia sebagai berikut.

Presentase Ejaan $=\frac{119}{202} \times 100 \%=58,9$ $1 \%$ *a) Sebab, di kampung Papa, cita-cita menjadi abdi Negara ... (B. Indonesia Wajib, wacana, 18)

*b) $\quad \ldots \quad$ sebagai bahasa Internasional ditunjukan nomor..... (B. Indonesia Peminatan, pertanyaan, 3) 
*c) ... khususnya terumbu karang biru (blue coral). (B. Indonesia Wajib, wacana, 12)

*d) (4) Kondisi masyarakat kita belum terbiasa dengan kebebasan yang menyebabkan kejutan budaya (culture shock). (B. Indonesia Peminatan, wacana, 15)

*e) 19. Contoh cara pengutipan yang benar dari sumber tertulis adalah... (B. Indonesia Peminatan, pertanyaan, 19)

Penulisan huruf kapital pada kata Negara dalam soal *a) tidak tepat karena huruf kapital dipakai sebagai huruf pertama unsur nama pangkat dan jabatan yang diikuti nama orang atau yang dipakai sebagai pengganti nama orang tertentu, nama tempat, atau nama instansi. Jadi, penulisan yang tepat sebagai berikut.

a) Sebab, di kampung Papa, cita-cita menjadi abdi negara

Penulisan huruf kapital pada kata Internasional dalam soal $*$ b) tidak tepat karena huruf kapital dipakai sebagai huruf pertama suku bangsa, nama bangsa, dan bahasa. Misalnya, "bangsa Indonesia, suku Dani, bahasa Inggris." Jadi, penulisan yang tepat sebagai berikut.
b) ... sebagai bahasa internasional ditunjukan nomor.....

Penulisan huruf miring yang tidak tepat terjadi pada kata blue coral dalam soal $*$ c) dan culture shock dalam soal $*$ d) karena berdasarkan aturan yang ada, huruf miring digunakan untuk menuliskan ungkapan atau kata dalam bahasa daerah atau bahasa asing kecuali yang sudah disesuaikan ejaannya. Jadi, pembetulan penulisan yang tepat sebagai berikut. c) ... khususnya terumbu karang biru (blue coral).

d) (4) Kondisi masyarakat kita belum terbiasa dengan kebebasan yang menyebabkan kejutan budaya (culture shock).

Penulisan huruf tebal yang tidak tepat terjadi dalam kalimat $*$ e) karena huruf tebal hanya digunakan untuk menegaskan bagian-bagian karangan, seperti judul buku, bab, atau subbab serta untuk menegaskan bagian tulisan yang sudah ditulis miring. Jadi, penulisan yang tepat sebagai berikut.

e) 19. Contoh cara pengutipan yang benar dari sumber tertulis adalah ...

Kesalahan dalam pemakaian huruf yang banyak ditemukan pada soal PAS mata pelajaran bahasa Indonesia wajib maupun peminatan adalah kesalahan dalam pemakaian huruf kapital dan kesalahan dalam pemakaian huruf miring. Penggunaan bentuk yang salah tersebut terdapat dalam pernyataan soal, jawaban, dan wacana.

Penulisan kata harus sesuai dengan Pedoman Umum Ejaan Bahasa Indonesia (PUEBI) yang sedang berlaku. Di bawah ini merupakan bentuk-bentuk kesalahan penulisan kata yang berperan sebagai perwakilan dari setiap jenis dan mata pelajaran.

*a) "Nanda, di sebelah toko Bunda ada kios yang dijual." (B. Indonesia Wajib, wacana, 21)

*b) D. Hampir semua penumpang berdoa ketika bus oleng di jalan yang menurun. (B. Indonesia Peminatan, pilihan jawaban, 7)

*c) D. bekerja samalah dengan baik dan jujur dalam melakukan sebuah pekerjaan 
(B. Indonesia Wajib, pilihan jawaban, 23)

*d) Kegiatan fashion muslimah yang diselenggarakan tiap tahun oleh Royal Plaza berkerjasama dengan sejunlah desainer muda ... (B. Indonesia Peminatan, wacana, 16)

*e) C. dialog antar tokoh (B. Indonesia Peminatan pilihan jawaban, 40)

Kesalahan penulisan kata terdapat pada kata took dalam soal *a), kata Hamper dalam soal *b), dan kata sejunlah dalam soal $*$ d) karena salah ketik (saltik). Jadi, pembetulan penulisn kata tersebut sebagai berikut.

a) "Nanda, di sebelah toko Bunda ada kios yang dijual."

b) D. Hampir semua penumpang berdoa ketika bus oleng di jalan yang menurun.

d) Kegiatan fashion muslimah yang diselenggarakan tiap tahun oleh Royal Plaza berkerja sama dengan sejumlah desainer muda ...

Kesalahan penulisan kata juga terdapat pada gabungan kata bekerja samalah dalam soal $*_{\mathrm{c}}$ ) dan kata berkerjasama dalam soal $*_{\mathrm{d}}$ ) karena gabungan kata yang mendapatkan awalan dan akhiran sekaligus ditulis secra serangkai, sedangkan gabungan kata yang mendapat awalan atau akhiran saja maka penulisannya ditulis terpisah. Jadi, pembetulan penulisan kata tersebut sebagai berikut.

c) D. bekerjasamalah dengan baik dan jujur dalam melakukan sebuah pekerjaan

d) Kegiatan fashion muslimah yang diselenggarakan tiap tahun oleh Royal Plaza berkerja sama dengan sejumlah desainer muda ...

Kesalahan penulisan kata juga terdapat pada kata berimbuhan antar tokoh dalam soal *e) karena bentuk terikat harus ditulis serangkai dengan kata yang mengikutinya. Jadi, pembetulan penulisan kata tersebut sebagai berikut.

e) C. dialog antartokoh

Kesalahan dalam penulisan kata yang banyak ditemukan pada soal PAS mata pelajaran bahasa Indonesia wajib maupun peminatan adalah kesalahan dalam penulisan gabungan kata dan kesalahan dalam penulisan kata (salah ketik). Penggunaan bentuk yang salah tersebut terdapat dalam pernyataan soal, jawaban, dan wacana.

Pemakaian tanda baca harus sesuai dengan Pedoman Umum Ejaan Bahasa Indonesia (PUEBI) yang sedang berlaku. Di bawah ini merupakan bentuk-bentuk kesalahan pemakaian tanda baca yang berperan sebagai perwakilan dari setiap jenis pemakaian tanda baca dan mata pelajaran.

*a) B. Teks yang bertujuan memberikan pemahaman yang benar kepada pembaca tentang fenomena alam atau sosial (B. Indonesia Wajib, pilihan jawaban, 49)

*b) E. Budi membaca kisah-kisah pahlawan lalu menuliskannya dalam novel sejarah (B. Indonesia Peminatan, pilihan jawaban, 6)

*c) 7) Kemudian, campuran itu dipanaskan dalam tungku pada suhu yang sangat tinggi. (B. Indonesia Wajib, wacana, 11)

*d) (3) Tata bahasa Indonesia tidak mengenal tenses, sehingga mudah dipelajari (B. Indonesia Peminatan, wacana, 4)

*e) Kalimat berikut yang menggunakan partikel -lah untuk menghaluskan nada perintah adalah ... (B. 
Indonesia

Wajib,

pertanyaan, 16)

*f) ... yang dicegatnya berdikitdikit dari orang- orang kampung lewat. (B. Indonesia Peminatan, wacana, 38)

*g) (5) Aplikasikan pada $\underline{5-10}$ tanaman yang terserang kutu daun ... (B. Indonesia, wacana Wajib, 27)

*h) Sebanyak 25 desainer muslimah akan memperagakan karyanya pada 12 - 14 Oktober 2018. (B. Indonesia Peminatan, wacana, 16)

*i) ..... Dela dan Tina sudah terlihat bersepeda bersama di sekitar taman. (B. Indonesia Wajib, wacana, 48)

*j) Di sisi lain, kegiatan tersebut.........menjadi tempat penyaluran bakat seni.........untuk mempererat tali persaudaraan ... (B. Indonesia Peminatan wacana, 8)

*k) (1)Dampak dari pengajaran tata bahasa yang berpusat pada kalimat ... (B. Indonesia Wajib, wacana, 40)

*1) Judul :Andy's Corner (B. Indonesia Peminatan, wacana, 23)

*m) ... berpola $\mathrm{S} / \mathrm{P} / \mathrm{O}$ Konjungsi $\mathrm{S} / \mathrm{P} / \mathrm{K}$ di bawah ini adalah ... (B. Indonesia Peminatan, pertanyaan, 6)

Pada soal *a) dan *b) merupakan kalimat yang berupa pernyataan. Dalam Pedoman Umum Ejaan Bahasa Indonesia dijelaskan bahwa setiap akhir kalimat pernyataan menggunakan tanda titik (.). Jadi, pembetulan pemakaian tanda baca tersebut sebagai berikut. a) B. Teks yang bertujuan memberikan pemahaman yang benar kepada pembaca tentang fenomena alam atau sosial.

b) E. Budi membaca kisah-kisah pahlawan lalu menuliskannya dalam novel sejarah.

Kesalahan penggunaan tanda baca koma ditemukan pada soal $* \mathrm{c}$ ) dan $*$ d) karena kata penghubung (konjungsi) tidak disertai tanda koma di awal maupun akhir kata. Maka pembetulan pemakaian tanda baca tersebut sebagai berikut.

c) 7) Kemudian campuran itu dipanaskan dalam tungku pada suhu yang sangat tinggi.

d) (3) Tata bahasa Indonesia tidak mengenal tenses sehingga mudah dipelajari.

Kesalahan penggunaan tanda hubung ditemukan dalam kata -lah pada soal *e) karena kata tersebut merupakan kata partikel, seharusnya menggunakan tanda hubung bukan menggunakan tanda pisah. Selain itu, kesalahan penggunaan tanda hubung ditemukan dalam kata orangorang pada soal $*_{f}$ ) karena tanda hubung ditulis tanpa spasi (jarak) jika digunakan sebagai penyambung unsur kata ulang. Maka pembetulan pemakaian tanda baca tersebut sebagai berikut.

e) Kalimat berikut yang menggunakan partikel -lah untuk menghaluskan nada perintah adalah ...

f) ... yang dicegatnya berdikitdikit dari orang-orang kampung lewat.

Kesalahan penggunaan tanda pisah ditemukan pada soal $* \mathrm{~g}$ ) dan $*$ h) karena tanda pisah digunakan diantara dua bilangan dan tanggal yang memiliki arti 'sampai dengan' ditulis tanpa spasi (jarak). Maka pembetulan pemakaian tanda baca tersebut sebagai berikut. 
g) (5) Aplikasikan pada 5-10 tanaman yang terserang kutu daun ...

h) Sebanyak 25 desainer muslimah akan memperagakan karyanya pada 12-14 Oktober 2018.

Kesalahan dalam pemakaian tanda elipsis ditemukan dalam soal $*_{\mathrm{i}}$ ) dan $*_{\mathrm{j}}$ ) karena tanda elipsis digunakan sebagai penunjuk bahwa dalam suatu kutipan atau kalimat ada bagian yang dihilangkan maka menggunakan jumlah titik tiga buah, jika pada akhir kalimat jumlah tititk menjadi empat buah karena diikuti oleh tanda titik. Penggunaan tanda elipsis juga didahului dan diikuti dengan spasi (jarak). Jadi, pembetulan contoh tersebut adalah sebagai berikut.

i) ..., Dela dan Tina sudah terlihat bersepeda bersama di sekitar taman.

j) Di sisi lain kegiatan tersebut ... menjadi tempat penyaluran bakat seni ... untuk mempererat tali persaudaraan

Kesalahan penggunaan tanda baca juga terdapat dalam kata (1)Dampak pada soal $* \mathrm{k}$ ) karena tanda kurung digunakan sebagai pengapit angka atau huruf yang berfungsi sebagai penanda pemerincian maka penulisannya diakhir tanda kurung diberi spasi (jarak). Penggunaan tanda baca titik dua dalam kata :Andy's pada nomor *1) seharusnya di beri jarak (spasi) karena tanda titik dua yang digunakan setelah ungkapan atau kata yang memerlukan pemerian maka penulisannya diberi spasi (jarak) di depan maupun di belakang tanda. Selain itu, penggunaan tanda garis miring juga ditemukan pada soal $*$ m) karena penggunaan tanda garis miring tidak didahului maupun diakhiri dengan spasi (jarak). Maka pembetulan pemakaian tanda baca tersebut sebagai berikut.

k) (1) Dampak dari pengajaran tata bahasa yang berpusat pada kalimat ...
1) Judul : Andy's Corner

m) ... berpola $\mathrm{S} / \mathrm{P} / \mathrm{O}$ konjungsi $\mathrm{S} / \mathrm{P} / \mathrm{K}$ di bawah ini adalah ...

Kesalahan ejaan yang banyak ditemukan pada soal PAS mata pelajaran bahasa Indonesia wajib maupun peminatan adalah kesalahan dalam pemakaian tanda baca elipsis. Penggunaan bentuk yang salah tersebut terdapat dalam pernyataan soal, jawaban, dan wacana. Padahal, ejaan merupakan salah satu yang harus diperhatikan dalam kebahasaan menyusun soal. Seperti yang telah dikemukakan oleh Fajarya (2017: 72) bahwa "Ejaan merupakan salah satu bentuk yang harus diperhatikan dalam menulis karena ejaan merupakan suatu kaidah atau ketentuan yang sudah ditetapkan dalam bahasa Indonesia." Sebuah tulisan entah tulisan apapun itu, akan dikatakan baik apabila menggunakan ejaan yang sesuai dengan kaidah yang berlaku.

Kesalahan berbahasa dalam bentuk pilihan ketepatan kata yang ditemukan pada soal Penilaian Akhir Semester gasal mata pelajaran Bahasa Indonesia kelas XI SMA Negeri di wilayah Sukoharjo berupa kesalahan ketepatan dan keserasian. Contoh kesalahan-kesalahan tersebut dapat didiskripsikan sebagai berikut.

*a) Bacalah paragraf berikut dengan cermat untuk menjawab soal nomor 27 dan 30. (B. Indonesia Wajib, petunjuk, 27)

*b) C. Argumentasi itu tidak lain daripada usaha untuk mengajukan bukti-bukti atau menentukan kemungkinankemungkinan ... (B. Indonesia Peminatan, pilihan jawaban, 19)

*c) A. Pelestarian dan mengembangkan Pantai Senggigi. (B. Indonesia Wajib, pilihan jawaban, 12)

*d) ... yakni faktor yang berasal dari luar bahasa atau biasa disebut dengan istilah faktor

BASASTRA Jurnal Bahasa, Sastra, dan Pengajarannya 
intrabahasa dan yang berasal dari bahasa itu sendiri atau biasanya disebut dengan istilah faktor ekstrabahasa. (B. Indonesia Peminatan, pilihan jawaban, 43)

Pemakaian kata dan dalam soal $*$ a) tidak tepat karena kata dan memiliki arti kesetaraan. Agar pernyataan tersebut memiliki pengertian yang lebih logis, maka diperlukannya pemilihan kata yang lebih tepat, yaitu kata sampai dengan yang menunjukkan arti hingga. Jadi, pembenaran kalimat sebagai berikut.

\section{a) Bacalah paragraf berikut dengan cermat untuk menjawab soal nomor 27 sampai dengan 30.}

Pemakaian kata daripada dalam soal *b) tidak tepat karena kata tersebut memiliki arti suatu perbandingan. Agar pernyataan tersebut memiliki artian yang lebih logis, maka diperlukannya pemilihan kata yang lebih tepat, yaitu kata merupakan. Sehingga pembenaran kalimat sebagai berikut.

b) C. Argumentasi itu tidak lain merupakan usaha untuk mengajukan bukti-bukti atau menentukan kemungkinankemungkinan ...

Kesalahan pemilihan kata juga terdapat dalam kata mengembangkan pada soal $*$ c) dan kata biasanya pada soal $* d$ ) karena kurang serasi dengan kata sebelumya dalam satu kalimat. Sehingga pembenaran kalimat sebagai berikut.

c) A. Pelestarian dan pengembangan Pantai Senggigi. (B. Indonesia Wajib, pilihan jawaban, 12)

d) ... yakni faktor yang berasal dari luar bahasa atau biasa disebut dengan istilah faktor intrabahasa dan yang berasal dari bahasa itu sendiri atau biasa disebut dengan istilah faktor ekstrabahasa.
Kesalahan berbahasa dalam bentuk penggunaan kata yang ditemukan pada soal Penilaian Akhir Semester gasal mata pelajaran Bahasa Indonesia kelas XI SMA Negeri di wilayah Sukoharjo berupa kesalahan penggunaan kata ragam tidak baku. Kata baku merupakan kata sesuai dengan ketentuan dan kaidah yang sedang berlaku. Contoh kesalahan-kesalahan tersebut dapat didiskripsikan sebagai berikut.

*a) ... dengan menggunakan bolpoint/pulpen yang bertinta hitam! (B. Indonesia Wajib, petunjuk, 6)

*b) ... sehingga lahir rasa kebangsaan dan ketaqwaan yang tinggi di dalam sanubari pelajar. (B. Indonesia Peminatan, wacana, 8)

$*_{c}$ ) C. rangkaian argument (B. Indonesia Wajib, pilihan jawaban, 14)

*d) B. Oleh karena itu, sistem rekruitmen harus diubah, termasuk pola pembinaan dan pendidikan. (B. Indonesia Peminatan, pilihan jawaban, 13)

Penggunaan kata tidak baku ditemukan pada kata bolpoint dalam soal *a), kata ketaqwaan dalam soal *b), kata argument dalam soal $*^{*}$ ), dan kata rekruitmen dalam soal $*$ d). Ragam baku dari kata-kata tersebut adalah sebagai berikut.

a) ... dengan menggunakan bolpoin/pulpen yang bertinta hitam! (B. Indonesia Wajib, petunjuk, 6)

b) ... sehingga lahir rasa kebangsaan dan ketakwaan yang tinggi di dalam sanubari pelajar. (B. Indonesia Peminatan, wacana, 8)

c) C. rangkaian argumen (B. Indonesia Wajib, pilihan jawaban, 14) 
d) B. Oleh karena itu, sistem rekrutmen harus diubah, termasuk pola pembinaan dan pendidikan.

Kesalahan berbahasa dalam bentuk penggunaan kata yang banyak ditemukan pada soal PAS mata pelajaran bahasa Indonesia wajib maupun peminatan adalah kesalahan dalam pilihan ketepatan kata pada soal. Penggunaan bentuk yang salah tersebut terdapat dalam pernyataan soal, jawaban, dan wacana. Padahal, menurut pendapat Sukmawaty (2017: 62) bahwa "Penggunaan kata secara tepat sesuai dengan situasi komunikasi merupakan hal yang paling penting agar apa yang dimaksudkan dapat dipahami."

Menurut pendapat Ayudia, dkk (2016: 40) bahwa pilihan kata dalam kalimat sangat mempengaruhi makna yang terdapat dalam sebuah kalimat tersebut. Pilihan kata yang dipakai harus sesuai dan tepat agar tidak memiliki makna ganda atau ambigu. Hal ini sependapat dengan Sumarwati (2013: 109) bahwa "Pilihan kata menunjuk pada pengertian penggunaan suatu kata, dari sejumlah besar kata yang dikuasai penulis." Oleh karena itu, seorang penulis soal harus memperkaya ilmu serta pengetahuan di bidang kebahasaan khususnya kosa kata karena bahasa yang benar dapat mempermudah peserta didik dalam memahami soal.

Kesatuan gagasan pada soal bisa menjadi tidak jelas dikarena kedudukan sebuah subjek atau predikatnya yang tidak begitu jelas, biasanya dikarena salah dalam penggunaan kata depan. Berikut merupakan bentuk kesalahan kalimat dalam kesatuan gagasan.

*a) Kalimat yang menyatakan penyebab ditunjukkan pada nomor .... (B. Indonesia Wajib, pertanyaan, 13)

*b) Agar memiliki kepaduan hubungan antarkalimat dalam paragraf tersebut dapat dipadukan dengan penanda hubung ... (B. Indonesia Peminatan, pertanyaan, 14)

$*_{c}$ ) Konflik membuat seseorang berbagai masalah termasuk masalah psikologis. (B. Indonesia Wajib, wacana, 35)

*d) Tikus yang terpapar. Semakin tinggi tingkah radiasi semakin sedikit testosterone dalam darah. (B. Indonesia Peminatan, wacana, 27)

Pernyataan dalam soal *a) dan *b) tidak terdapat bagian kata yang berfungsi menerangkan subjek atau tidak terdapat predikat, sehingga mengaburkan pengertian yang dimaksudkan. Maka pernyataan pada soal tersebut perlu diperjelas dengan adanya kata yaitu. Pembenaran kalimat tersebut sebagai berikut.

a) Kalimat yang menyatakan penyebab, yaitu ditunjukkan pada nomor ...

b) Agar memiliki kepaduan hubungan antarkalimat dalam paragraf tersebut dapat dipadukan dengan penanda hubung, yaitu ...

Pernyataan soal $*_{\mathrm{c}}$ ) dan $*$ d) menjadi ambigu sehingga kalimat-kalimat tersebut tidak memiliki kesatuan gagasan. Jadi, pembenaran kalimat tersebut sebagai berikut.

c) Konflik membuat seseorang memiliki berbagai masalah termasuk masalah psikologis.

d) Tikus yang terpapar gelombang elektromagnetik, semakin tinggi tingkat radiasi semakin sedikit testosterone dalam darah.

Kehematan kalimat dalam penulisan soal merupakan penggunan kalimat yang tidak memerlukan kata, frasa, atau bentuk lain yang dianggap tidak penting atau tidak perlu, yang menjadikan maksud kalimat 
tersebut tidak jelas (Kurniawan, 2015: 126). Berikut merupakan perwakilan bentuk kesalahan dalam kehematan kalimat.

*a) Setelah itu, campuran adonan itu dibentuk menjadi botol dengan cetakan. (B. Indonesia Wajib, wacana, 11)

*b) Seseorang yang memiliki ilmu pengetahuan yang luas dan berpendidikan tinggi, ia akan seperti padi. (B. Indonesia Peminatan, wacana, 11)

*c) Wanita hamil yang memakai HP yang meskipun hanya 2 atau 3 kali dalam sehari, cukup untuk menimbulkan resiko bayi mereka terkena penyakit hiperaktif dan bisa mengalami kesulitan dalam pemahaman/proses belajar, emosi dan sosialisasi anak pada saat sekolah. (B. Indonesia Peminatan, wacana, 27)

*d) Orang yang tahu sebab yang sebenarnya, tiadalah berani menceritakan kepada orang lain. (B. Indonesia Wajib, wacana, 44)

Soal-soal di atas merupakan contoh soal yang terdapat kesalahan penggunaan kehematan kalimat sehingga pembenaran kalimat tersebut sebagai berikut.

a) Setelah itu, campuran adonan dibentuk menjadi botol dengan cetakan.

b) Seseorang yang memiliki ilmu pengetahuan luas dan berpendidikan tinggi, ia akan seperti padi.

c) Wanita hamil yang memakai HP meskipun hanya 2 atau 3 kali dalam sehari, cukup untuk menimbulkan resiko bayi mereka terkena penyakit hiperaktif dan bisa mengalami kesulitan dalam pemahaman/proses belajar, emosi dan sosialisasi anak pada saat sekolah.

d) Orang yang tahu sebab sebenarnya, tiadalah berani menceritakan kepada orang lain.

Kesalahan berbahasa dalam bentuk penggunaan kalimat yang banyak ditemukan pada soal PAS mata pelajaran bahasa Indonesia wajib maupun peminatan adalah kesalahan dalam kesatuan gagasan pernyataan pada soal. Penggunaan bentuk yang salah tersebut terdapat dalam pernyataan soal, jawaban, dan wacana. Seperti yang telah dijelaskan oleh Sugono (2009) yang menyebutkan bahwa syarat utama yang perlu diperhatikan dalam pembentukkan sebuah kalimat, yaitu adanya pemutasi unsur kalimat dan unsur predikat. Perubahan urutan atau pemutasi biasanya terdapat pada subjek serta predikat dalam suatu kalimat (Ariningsih, Sumarwati, \& Saddhono, 2012). Apabila perubahan predikat serta subjek tersebut tidak menimbulkan artian baru maka pernyataan tersebut dapat disebut kalimat.

\section{Faktor Penyebab Kesalahan Berbahasa}

Hasil penelitian yang mencakup faktor-faktor penyebab kesalahan berbahasa pada soal Penilaian Akhir Semester gasal mata pelajaran Bahasa Indonesia kelas XI SMA Negeri di wilayah Sukoharjo akan diuraikan dengan secara terperinci pada bagian ini. Peneliti melakukan wawancara dan menyebarkan kuesioner dengan guru bahasa Indonesia serta tim penyusun soal bahasa Indonesia kelas XI SMA Sukoharjo, yaitu tim MGMP wilayah kabupaten Sukoharjo. Setelah melakukan wawancara dengan narasumber tersebut, dapat disimpulkan bahwa terjadinya berbagai bentuk kesalahan berbahasa Indonesia disebabkan oleh beberapa faktor. Terdapat dua faktor yang dapat menjadi penyebab kesalahan berbahasa pada soal Penilaian Akhir Semester gasal tersebut, yaitu faktor internal berasal dari dalam penyusun soal meliputi pengetahuan, pemahaman, dan 
ketelitian. Sedangkan faktor eksternal berasal dari luar penyusun soal meliputi waktu dan lingkungan sekitar.

Faktor internal yang memengaruhi penggunaan bahasa dalam soal, yaitu kurangnya ketelitian dalam menyusun soal, kurang memahami kaidah kebahasaan, kebiasaan mengandalkan tim editing, dan kebiasaan yang salah. Sedangkan faktor eksternal yang memengaruhi penggunaan bahasa dalam soal, yaitu rentan waktu yang singkat, dan tidak ada evaluasi.

Faktor utama yang mempengaruhi kesalahan berbahasa pada soal adalah rentan waktu yang singkat. Penyusunan soal membutuhkan waktu yang lumayan lama, namun peserta didik mengerjakan soal tersebut dengan rentan waktu yang relatif singkat. Seperti pendapat Hazraini (2017: 111-112) bahwa "Soal dalam bentuk pilihan ganda cara membuatnya sulit dan sangat rumit sehingga membutuhkan waktu yang cukup lama, tetapi bagi peserta didik sangat cepat menjawabnya walaupun hasilnya masih belum sesuai dengan kunci jawaban yang diharapkan."

\section{Dampak Kesalahan Berbahasa}

Berdasarkan hasil wawancara dengan beberapa peserta didik yang merupakan perwakilan dari kelas tinggi, sedang, dan rendah dari dua SMA Negeri di wilayah Sukoharjo, dapat diketahui seberapa besar dampak yang ditimbulkan dari kesalahan berbahasa Indonesia pada penulisan soal Penilaian Akhir Semester gasal mata pelajaran Bahasa Indonesia kelas XI SMA Negeri di wilayah Sukoharjo. Dari enam peserta didik yang digunakan sebagai sampel, sebanyak empat peserta didik mengalami kesulitan dalam memahami soal tetapi dapat menjawab soal tersebut dengan benar dan dua peserta didik yang mengalami kesulitan dalam memahami soal sehingga tidak mampu menjawab soal dengan benar. Selain itu, presentase ketepatan peserta didik dalam menjawab soal hanya sebesar $68 \%$ untuk mata pelajaran bahasa
Indonesia Peminatan dan $77 \%$ untuk mata pelajaran bahasa Indonesia Wajib.

\section{Pemahaman Guru Terhadap Kaidah Penyusunan Soal}

Dari hasil wawancara, guru yang ditunjuk sebagai penyusun soal Penilaian Akhir Semester gasal mata pelajaran Bahasa Indonesia kelas XI SMA Negeri di wilayah Sukoharjo menjelaskan bahwa soal yang dibuatnya merupakan jenis soal pilihan ganda. Kaidah penyusunan soal pilihan ganda harus memperhatikan tiga aspek penting, yaitu mengenai materi, konstruksi, dan bahasa. Namun, guru hanya memahami mengenai materi dan konstruksi dalam soal saja. Peneliti juga melakkan recheck dengan menggunakan hasil kuesioner yang telah disebarkan kepda guru bahasa Indonesia yang hasilnya bahwa guru hanya memahami kaidah penulisan soal berupa materi dan konstruksi saja. Berikut kutipan hasil kuesioner.

"Kaidah penulisan soal pilihan ganda berupa: 1) soal yang dibuat sesuai indikator, 2) pilihan jawaban homogen dan logis, 3) setiap soal hanya memiliki satu jawaban yang benar." (Jaka Santosa)

Jawaban serupa juga dijelaskan oleh Utami Nugraheni yang merupakan salah satu guru bahasa Indonesia di kabupaten Sukoharjo dan anggota MGMP wilayah kabupaten Sukoharjo, berikut kutipan pendapat tersebut.

"Kaidah penyusunan soal pilihan ganda: 1) disesuaikan dengan indikator yang akan diukur. 2) pilihan harus homogen. 3) hanya ada satu jawaban yang benar."

\section{Ketepatan Penyusunan Soal dengan Kaidah Penyusunan Soal}

Peneliti melakukan analisis pada soal Penilaian Akhir Semester gasal mata pelajaran Bahasa Indonesia kelas XI SMA Negeri di wilayah Sukoharjo untuk 
mendapatkan data terkait dengan ketepatan penyusunan soal sesuai dengan kaidah. Kegiatan menganalisis tersebut dalam penalitian ini adalah mengidentifikasi jenis kesalahan dalam penyususnan soal yang tidak sesuai dengan kaidah penyusunan soal. Kesalahan tersebut diklasifikasikan ke dalam dua aspek, yaitu aspek materi serta aspek konstruksi. Berdasarkan dari hasil analisis yang dilakukan oleh peneliti bahwa kaidah penyusunan soal yang terdapat dalam soal Penilaian Akhir Semester gasal mata pelajaran Bahasa Indonesia kelas XI SMA Negeri di wilayah Sukoharjo belum sepenuhnya menggunakan kaidah penyusunan soal yang sedang berlaku.

Berdasarkan hasil penelitian ditemukan jumlah kesalahan dalam aspek materi sebanyak 13 kesalahan. Sedangkan jumlah kesalahan dalam aspek konstruksi sebanyak 11 kesalahan. Selanjutnya, peneliti akan menghitung presentase setiap aspek kesalahan kaidah penyusunan soal pada soal. Penghitungan presentase kesalahan kaidah penyusunan soal dapat dihitung dengan rumus berikut.

Presentase Kesalahan $=\frac{\text { Jumlah kesalahan tiap jenis }}{\text { jumlah kesalahan total }} \times 100 \%$

Dengan demikian, dapat dihitung presentase kesalahan berbahasa Indonesia sebagai berikut.

Presentase Materi $=\frac{13}{24} \times 100 \%=54$, $16 \%$

Presentase Konstruksi $=\frac{11}{24} \times 100 \%$ $=45$,

$83 \%$

Dari segi materi, beberapa butir soal tidak dirumuskan sama dengan indikator soal dalam kisi-kisi yang telah dibuat sebelumnya dan beberapa pilihan jawaban tidak dirumuskan secara homogen. Padahal tujuan dari soal tersebut untuk mengukur dan menilai sehingga dapat menghasilkan nilai yang melambangkan prestasi. Hal tersebut sejalan dengan pendapat yang dipaparkan oleh Sudijono (2005: 67) bahwa:

Tes hasil belajar merupakan cara yang dapat dipergunakan atau prosedur yang perlu ditempuh dalam rangka pengukuran dan penilaian di bidang pendidikan, yang berbentuk pemberian tugas atau serangkaian tugas baik berupa pertanyaan-pertanyaan maupun perintah-perintah yang harus dikerjakan oleh peserta didik, sehingga dapat dihasilkan nilai yang melambangkan tingkah laku atau prestasi.

Sedangkan dari segi konstruksi, beberapa butir soal dirumuskan dengan menggunakan pernyataan yang memiliki sifat negatif ganda. Selain itu, pilihan jawaban yang dirumuskan memiliki panjang kalimat yang tidak relatif sama dan yang berbentuk angka tidak tersusun berdasarkan urutan besar kecilnya nilai angka tersebut.

\section{SIMPULAN}

Berdasarkan hasil penelitian yang telah dilakukan terhadap adanya kesalahan penggunaan bahasa Indonesia serta kaidah penyusunan soal dalam penulisan soal Penilaian Akhir Semester Gasal mata pelajaran Bahasa Indonesia kelas IX SMA Negeri di wilayah Sukoharjo tahun ajaran 2018/2019 seperti yang telah dijelaskan dalam bab IV maka dapat disimpulkan sebagai berikut. (1) Kesalahan berbahasa dalam penulisan soal Penilaian Akhir Semester Gasal mata pelajaran Bahasa Indonesia kelas IX SMA Negeri di wilayah Sukoharjo dibedakan berdasarkan ketentuan yang ada, yaitu jenis kesalahan yang terjadi pada penggunaan ejaan didominasi oleh kesalahan dalam pemakaian tanda baca, jenis kesalahan

BASASTRA Jurnal Bahasa, Sastra, dan Pengajarannya 
yang terjadi pada penggunaan kata didominasi oleh kesalahan pilihan kata yang digunakan, dan jenis kesalahan yang terjadi pada penggunaan kalimat didominasi oleh kesatuan gagasan dalam merumuskan pernyataan soal. (2) Kesalahan berbahasa tersebut disebabkan oleh beberapa faktor, yaitu berupa faktor internal dan faktor eksternal. Faktor internal yang memengaruhi penggunaan bahasa dalam soal, yaitu kurangnya ketelitian dalam menyusun soal, kurang memahami kaidah kebahasaan, kebiasaan mengandalkan tim editing, dan kebiasaan yang salah. Sedangkan faktor eksternal yang memengaruhi penggunaan bahasa dalam soal, yaitu rentan waktu yang singkat dan tidak ada evaluasi. (3) Kesalahan berbahasa tersebut menimbulkan dampak yang signifikan karena dari semua peserta didik yang melakukan wawancara merasa kesulitan dalam memahami maksud soal karena kesalahan penggunaan bahasa tersebut. Namun 4 dari 6 peserta didik yang melakukan wawancara tetap bisa menjawab soal dengan benar walaupun mengalami kesulitan dalam memahami maksud soal tersebut. Hal tersebut juga dibuktikan dalam hasil penilaian pekerjaan peserta didik. Presentase ketepatan peserta didik dalam menjawab soal hanya sebesar $68 \%$ untuk mata pelajaran bahasa Indonesia Peminatan serta $77 \%$ untuk mata pelajaran bahasa Indonesia Wajib. (4) Guru bahasa Indonesia yang ditunjuk sebagai penyusun soal Penilaian Akhir Semester gasal mata pelajaran Bahasa Indonesia kelas XI SMA Negeri di wilayah Sukoharjo tahun ajaran 2018/2019 dan anggota MGMP wilayah kabupaten Sukoharjo kurang memahami kaidah penyusunan soal baik secara teori maupun praktik. (5) Kaidah penyusunan soal yang terdapat dalam soal Penilaian Akhir Semester gasal mata pelajaran Bahasa Indonesia kelas XI SMA Negeri di wilayah Sukoharjo tahun ajaran 2018/2019 belum sepenuhnya sesuai dengan kaidah penyusunan soal yang sedang berlaku baik dari aspek materi maupun aspek konstruksi. Kesalahan dari aspek materi didominasi oleh kesalahan dalam perumusan butir soal yang tidak sesuai dengan indikator soal pada kisi-kisi. Sedangkan kesalahan dari aspek konstruksi didominasi oleh kesalahan dalam perumusan pilihan jawaban berupa angka tidak disusun secara berurutan dari kecil ke besar maupun sebaliknya.

\section{REFERENSI}

Ariningsih, N.E., Sumarwati, Saddhono, K. (2012). Analisis Kesalahan Berbahasa Indonesia dalam Karangan Eksposisis Siswa Sekolah Menengah Atas. BASASTRA Jurnal Penelitian Bahasa, Sastra Indonesia dan Pengajarannya (1)1 40-53

Ayudia, dkk. (2016). Analisis Kesalahan Penggunaan Bahasa Indonesia dalam Laporan Hasil Observasi pada Siswa SMP. BASASTRA Jurnal Penelitian Bahasa, Sastra Indonesia dan Pengajarannya, 4 (1), 34-49.

Fajarya, N. \& Azhar U. (2017). Analisis Kesalahan Penggunaan Ejaan dalam Karangan Narasi Siswa Kelas X

SMA Swasta Taman Siswa Binjai Tahun Pembelajaran 2016/2017. Jurnal Basastra, 6 (2), 70-79.

Hazraini. (2017). Upaya Meningkatkan Kompetensi Guru Kelas dalam Penyusunan Soal Pilihan Ganda yang Baik dan Benar Melalui Pendampingan Berbasis KKG Semester Satu Tahun Pelajaran 2017/2018 di SD Negeri 40 Cakranegara. Jurnal Pendidikan Mandala, 2 (2), 111-121.

Kurniawan, I. (2015). EYD Ejaan Yang Disempurnakan. Bandung: Nuansa Cendikia 
Sudijono, A. (2005). Pengantar Evaluasi

Pendidikan. Jakarta: PT Raja

Grafindo.

Sugono, D. (2009). Mahir Berbahasa Indonesia dengan Benar. Jakarta: Gramedia Pustaka Utama.

Sukmawaty. (2017). "Analisis Kesalahan Berbahasa Indonesia pada Skripsi Mahasiswa Program Studi Sistem Informasi Sekolah Tinggi Manajemen Informatika dan Komputer (STMIK) Kharisma Makasar". Jurnal Retorika, 10 (1), 56-65.

Sumarwati. (2013). Menulis Karya Ilmiah dalam Bahasa Indonesia. Surakarta: UNSPress.

Tritantining, A. M. (2013). "Kesalahan Berbahasa pada Soal-soal Ulangan Akhir Semester Gasal Mata Pelajaran Bahasa Jawa SD Negeri Se-Kabupaten Pati Tahun Ajaran 2012/2013". Piwulang Jawi: Journal of Javanese Learning and Teaching, 2 (1), 1-5. 